BULLETIN Bulletin hispanique

HISPANIQUE Université Michel de Montaigne Bordeaux

117-1 | 2015

Les poètes des rhéteurs

Loreto Busquets, Pensamiento social y político en la literatura española. Desde el Renacimiento hasta el siglo $X X$

Editorial Verbum, Madrid, 2014

Mercè Boixareu

(2) OpenEdition

Journals

Edición electrónica

URL: https://journals.openedition.org/bulletinhispanique/3932

DOI: 10.4000/bulletinhispanique.3932

ISSN: $1775-3821$

Editor

Presses universitaires de Bordeaux

Edición impresa

Fecha de publicación: 1 junio 2015

Paginación: 378-381

ISBN: 979-10-300-0174-7

ISSN: 0007-4640

Referencia electrónica

Mercè Boixareu, «Loreto Busquets, Pensamiento social y político en la literatura española. Desde el Renacimiento hasta el siglo XX», Bulletin hispanique [En línea], 117-1 | 2015, Publicado el 01 septiembre 2015, consultado el 11 febrero 2022. URL: http://journals.openedition.org/bulletinhispanique/3932 ; DOI: https://doi.org/10.4000/bulletinhispanique.3932

Este documento fue generado automáticamente el 11 febrero 2022.

Tous droits réservés 


\title{
Loreto Busquets, Pensamiento social y político en la literatura española. Desde el Renacimiento hasta el siglo XX
}

Editorial Verbum, Madrid, 2014

\author{
Mercè Boixareu
}

\section{REFERENCIA}

Loreto Busquets, Pensamiento social y político en la literatura española. Desde el Renacimiento hasta el siglo XX. Madrid, Editorial Verbum, 2014, 393 p. ISBN 978-84-7962-988-5.

Loreto Busquets, autora de varios libros y artículos sobre las literaturas hispánicas, traductora de Cellini y Leopardi, directora de la revista Studi ispanici, nos ofrece en este libro una selección de sus artículos. En todos ellos domina la reflexión interpretativa sobre el pensamiento social y político que, de forma explícita o por alusiones significativas, se descubre en las distintas obras objeto de estudio. El análisis textual se enmarca siempre en los contextos sociohistóricos de producción, relacionándolos con las teorías estéticas o con las teorías histórico-políticas de cada momento, a la vez que se relacionan con sus fuentes y con textos coetáneos de otras culturas en un interesante acercamiento comparatista.

Esta metodología ilustra el primer capítulo, «El pensamiento renacentista en el Faetón de Alamanni y de Aldana». No se trata de un simple estudio comparatista entre el poeta italiano y su traducción-interpretación española del mito ovidiano. El interés estriba en que mediante estos textos, el análisis se adentra en las cuestiones filosóficas y morales que se plantean en el Renacimiento y que el mito ilustra: un nuevo antropocentrismo que a la vez es resultado del «olvido» de Dios, posiciona al hombre frente al universo y le confiere una nueva "visión» del mismo. El estudio se completa no sólo con reproducciones iconográficas de la época, sino con referencias a los maestros pensadores del momento: Ficino, Castiglione, Montaigne entre otros. 
3 En los dos textos sobre la obra de Calderón, «Los dramas de Calderón Hercules ad bivium y La vida es sueño o la apología de la Monarquía cristiana», la autora penetra en la voluntad característica del dramaturgo de significar ideas, evidente en los Autos Sacramentales, pero que puede pasar desapercibida en las obras de entretenimiento. A través del análisis de algunos textos, se muestran los conceptos que el jesuita confronta con la apologética pascaliana: la importancia de la razón y de la libertad frente a la fe y la gracia, la conciencia de la historia como contingencia y la defensa de la religión natural frente a la revelada. Estos aspectos se estudian de forma especial en La vida es sueño, obra en la que la apología de la monarquía implica la sujeción de un pueblo que, aunque crítico con el tirano, nunca llega a ser subversivo. A la oposición tiranopríncipe se añade el principio de «educabilidad» de este último, vinculada a la legitimidad de la monarquía. La respuesta o decisión ética final del «falso temor», la prudencia, se interpreta aquí como emancipación de la «omnisciente vigilancia del hegemonikon divino» y, esta vez sí, se relaciona con la apuesta pascaliana.

4 La última obra barroca estudiada, siempre teniendo muy en cuenta la teoría política de la época -Saavedra Fajardo y sobre todo Maquiavelo-, es la versión de Rojas Zorrilla del tema literario de base histórica de Tarquino y Lucrecia: «Lucrecia y Tarquino, o el conflicto entre el fin y los medios». En él se analizan los comportamientos de los distintos personajes, pero especialmente el conflicto personal, social y político del Tirano. La autora lamenta la supresión de las posibilidades «revolucionarias» del conflicto y su reducción a un drama de honor, con lo que el sacrificio de Lucrecia pierde las posibilidades reivindicativas de otras versiones del mito.

5 La época a la que la autora dedica mayor atención es el siglo XVIII. Como pórtico a este siglo puede considerarse el capítulo «Modelos humanos en el teatro español del siglo XVIII» en el que se muestra la aparición de nuevos personajes y con ellos de nuevos valores: el ciudadano frente al súbdito, la felicidad como imperativo existencial, el nuevo estoicismo como equilibrio y auto-control $y$, en definitiva, una nueva ética basaba en la moral natural frente a la moral cristiana. En la comedia, los personajes representan la nueva clase burguesa y sus nuevos valores basados en el trabajo (importancia del dinero) y la prudencia, ejemplarizando todos ellos comportamientos «razonables». Especialmente interesante es la consideración de las nuevas figuras femeninas, entregadas a la tareas domésticas, en actitudes de moderación y recato.

6 Los estudios sobre este siglo se continúan con uno de los capítulos más interesantes de este libro, «La tragedia neoclásica española y el ideario de la Revolución Francesa». En él, tras unas reflexiones introductorias, basadas a la vez en las ideas estéticas que normativizan el género, en la sociología de la literatura -autores, críticos-, y en la consideración del público receptor, la autora reivindica la existencia de un teatro español «revolucionario», con referencias constantes a la situación histórica y a las traducciones-alteraciones de los autores del país que lleva a cabo la Revolución, especialmente Voltaire y Rousseau. Basándose la autora en un corpus de más de doce obras (entre 1751 y 1805), estudia los procedimientos de transposición de los temas históricos -Roma, Numancia- o de mitos literarios -Idomeneo, Lucrecia, Virginia- entre otros, para mostrar cómo, a pesar de las dificultades planteadas por los censores, el teatro neoclásico de la época abre una brecha ideológica en la que se representa la conquista de la libertad perdida, el «advenimiento» de la Verdad recuperada por la virtud de los protagonistas de la Historia, las ideas ilustradas y los valores reivindicados en el proceso ideológico que prepara y que es coetáneo a la Revolución Francesa. 
7 Los estudios siguientes se basan en obras puntuales, aunque tienen en común, en lo que se refiere a la recreación de los mitos, la Lucrècia de Joan Ramis i Ramis, y el Idomeneo de Cienfuegos -«El ateísmo de Idomeneo, tragedia filosófica»-, el rigor con el que se estudia el origen grecolatino y las distintas versiones más modernas de los mismos, especialmente las francesas y las operísticas, así como los significados varios resultantes de su tratamiento. En el Idomeneo es importante destacar la reflexión que se aporta en las páginas iniciales, acerca de la utilización de las temáticas griegas y de la historia de Roma, teniendo en cuenta que las primeras, al considerar un sacrificio humano, se adentran en el cuestionamiento de la divinidad, mientras que en las romanas, más cercanas y más propiamente históricas, el cuestionamiento es político, al mostrar al pueblo enfrentado al despotismo del Tirano. Destacaría en el estudio sobre la Lucrecia de Ramis una atención especial prestada a las posibilidades significativas de las unidades de tiempo y espacio, considerando, como en el estudio de Moratín, el valor distinto de las escena y de lo que acontece en el exterior. Siguiendo esta metodología formalista, es interesante observar el estudio de significados que se hace de ciertas figuras retóricas y muy especialmente de los pronombres personales: la evolución de los distintos usos del yo, como conciencia de pasión frente al yo voluntad, en el caso de Tarquino, mientras que en el caso de Lucrecia se muestra el interés de la duda sobre el valor del sacrificio. El mal se interpreta dentro de la «ejemplaridad negativa», máximo exponente del didactismo plural que se descubre en el texto. La calificación de filosófica conviene a la tragedia de Idomeneo, a causa de la dialéctica esencial en la que se confrontan las ideas como mostración de la religión como impostura y la falta de razón crítica. Este capítulo se puede relacionar con "Cienfuegos, philosophe», en el que se muestra cómo la poesía del autor, plagada de los «modelos humanos» estudiados en un capítulo anterior, refleja la profunda interrogación sobre nuestros orígenes (Caos), un Eros vinculado a la Naturaleza y que se homologa con la Razón y la Virtud.

8 En «Ambivalencia ideológica de la burguesía ilustrada en El sí de las niñas» de Moratín, el análisis del texto muestra los valores del conservadurismo en los que se mueve la burguesía y lamenta que la obra «queda, pues, en el panorama del teatro español, como testimonio de la inutilidad de la evolución del pensamiento en una historia inmóvil».

9 Más «móvil» es el capítulo «La reelaboración de las fuentes en Polixena de José Marchena», no sólo por lo que supone la recuperación crítica de una obra poco estudiada, sino por la denuncia que en ella se realiza a propósito de la superstición y de las costumbres inhumanas derivadas de la religión. Una vez más, resulta particularmente enriquecedor el estudio de las fuentes, del mito, y de sus variantes, especialmente la versión de Racine y su relación con la figura de Andrómaca.

Ya en el siglo XIX, son dos los capítulos dedicados al Duque de Rivas. En «Don Alvaro, o la fuerza de la historia» se estudia al personaje y su relación con quienes le rodean, como un nuevo sujeto histórico, producto de las Luces, especialmente de Rousseau: en su lucha por la libertad y contra el destino, «en su radical desobediencia» al Padre, D. Alvaro se nos muestra como un nuevo Prometeo que, aunque derrotado, significa la rebeldía inevitable y el proceso doloroso de liberización de quien se ha nutrido del ideario ilustrado. En «Racismo de estado y limpieza étnica en La morisca de Alajuar del Duque de Rivas», obra situada en 1609-10 (la expulsión de los moriscos), la autora nos ofrece su visión crítica de un final feliz y acomodaticio, frente a una problemática muy actual, la de la discriminación racial y los rechazos y barbaries que conlleva. 
11 En «Ideario reaccionario en la Virginia de Tamayo y Baus» el estudio muestra cómo se puede «manipular» un mito intrínsecamente liberal y revolucionario y convertir la obra que lo sustenta -que no el propio mito- en la expresión y divulgación del conservadurismo procedente de la Constitución de 1848. El interés del estudio estriba no sólo en el análisis de diálogos y comportamientos (Virginia como ideal de hija, esposa sumisa y su destino de madre), sino en la presentación de la intencionalidad autorial (Prólogo) y en la contextualización histórica, a partir del cambio jurídico constitucional.

El capítulo «El capitalismo industrial y financiero en La febre d'or de Narcís Oller», está presentado en subcapítulos referidos al espacio de la obra en la Barcelona de principios de 1880: Los barrios barceloneses: de Pedralbes a Sant Martí (...) Llotja (...) La casa (...) Del Liceu al Hipòdrom (...) La sala Parés (...) etc.. El seguimiento que se hace es extremadamente atractivo y produce una admiración e interés contagiosos. Esta Barcelona no es simple decorado; sus casas, sus calles y sus gentes son el resultado de la historia social que precede y de sus transformaciones, y su particular protagonismo acompaña y significa los nuevos cambios: la vida de los ridículos nuevos ricos, los de los poderes financieros que el autor denuesta en favor de la sociedad trabajadora vinculada al poder del capitalismo industrial. No así la autora del artículo, quien denuncia el silencio de Oller sobre los conflictos sociales de la época.

Finalmente «Historicismo y antihistoricismo en El pianista de Vázquez Montalbán» es una lectura original, arriesgada, a la vez que oportuna y aportativa de la novela de este autor, bajo la luz del concepto de Historia de Walter Benjamin. La autora hace un seguimiento del texto narrativo, que completa con la obra del mismo autor, aparecida el mismo año que la novela, la Crónica sentimental de la Transición. El estudio muestra como la estructura fragmentaria de la obra, los «trozos» y «visiones», y el constante «diálogo» de los protagonistas nos confronta con el doble presente de Benjamin, y nos remite a nuestro propio presente lector, de desafecciones políticas.

Resumiendo, podemos decir que es este un libro particularmente interesante que, en sus distintos capítulos, ahonda en los textos con un variado aparato crítico y con amplios conocimientos de las fuentes clásicas originales y de las literaturas italiana y francesa principalmente. Las reflexiones que se aportan, rigurosamente fundadas, resultan no sólo ricas en ideas y sugerentes, sino a menudo innovadoras, de forma que, como en el caso de la tragedia neoclásica, rompen esquemas recibidos e invitan a un replanteamiento de algunos aspectos de las Historias de la literatura española.

\section{AUTORES}

\section{MERCÈ BOIXAREU}

Universidad nacional de educación a distancia, Madrid 